\title{
NILAI BUDAYA MASYARAKAT SUMBAWA DI PULAU LOMBOK (TINJAUAN TERHADAP AMA SAMAWA)
}

\section{THE CULTURAL VALUES OF SUMBAWA ETHNIC COMMUNITY IN LOMBOK: A STUDY OF AMA SAMAWA (SAMAWA PROVERB)}

\author{
Aditya Wardhani \\ Kantor Bahasa Provinsi Nusa Tenggara Barat \\ Jalan dr.Sujono, Kelurahan Jempong Baru, Kecamatan Sekarbela, Mataram \\ adityawardhani20@gmail.com \\ Tanggal naskah masuk: 22 September 2012 \\ Tanggal revisi terakhir: 20 Oktober 2012
}

\begin{abstract}
This is a study of cultural values of Sumbawa ethnic community in Lombok. The study is conducted by studying Ama Samawa (Samawa proverb). The study is aimed at revealing a form and cultural values in Ama Samawa among Sumbawa ethnic community in Lombok. In this study, Ethno linguistics method is applied and data is collected through observation and interview withthe primary informants from Rempung and Kuang Berora village. The analysis result shows that there is a correlation between the content of Ama Samawa and the cultural values of its speakers. The cultural values in Ama Samawa are classified based on their semantic meaning or information. As a conclusion, the relationship between human being and life bearing on values ofwisdom,desire and feeling.
\end{abstract}

Keyword: cultural values, ama Samawa

\section{Abstrak}

Tulisan ini mengkaji nilai budaya masyarakat Sumbawa di Pulau Lombok dengan mengamati ama (peribahasa) samawa. Kajian ini bertujuan untuk menampilkan wujud dan nilai budaya yang terdapat pada ama (peribahasa) samawa, pada masyarakat Sumbawa di Pulau Lombok. Metode yang digunakan adalah etnolinguistik. Pengumpulan data dilakukan dengan teknik observasi dan wawancara terhadap informan kunci di Desa Rempung dan Dusun Kuang Berora. Dari analisis terhadap ama samawa yang ada, dapat disimpulkan bahwa terdapat keterkaitan antara wujud ama samawa tersebut dengan nilai budaya masyarakat penuturnya. Nilai budaya yang terkandung dalam ama samawa ini dikelompokan berdasarkan makna atau informasinya. Artinya, hakikat hubungan manusia dengan hidup ini memuat tentang nilai yang mengacu pada kebijaksanaan, hasrat, dan perasaan.

Kata Kunci: nilai budaya, ama samawa

\section{Pendahuluan}

Kedatangan etnis Sumbawa ke Pulau Lombok yang bermula pada awal abad ke-18 tentu akan berimplikasi pada terjadinya kontak bahasa dan budaya sehingga menuntut hadirnya bahasa yang mampu menjembatani segala kepentingan mereka. Fenomena kontak bahasa tersebut masih ditemukan pada masyarakat Sumbawa sebagai masyarakat pendatang di Pulau Lombok karena masyarakat Sumbawa 
selalu berkomunikasi dengan etnis pribumi (etnis Sasak) dan etnis pendatang yang lain yang hidup berdampingan dengan mereka.

Komunitas Sumbawa yang terdapat di Pulau Lombok tersebar di wilayah Kodya Mataram, Kabupaten Lombok Barat, Kabupaten Lombok Tengah, dan Kabupaten Lombok Timur. Ama Samawa yang dikaji dalam tulisan ini ditemukan pada ini komunitas Sumbawa yang terdapat di Kabupaten Lombok Timur yaitu di Desa Kuang Beroradan Desa Rempung.

Budaya masyarakat Sumbawa di Pulau Lombok yang merujuk pada konsep-konsep abstrak yang hidup dalam masyarakat, mengenai apa yang dianggap penting dan berharga, tetapi juga mengenai apa yang dianggap remeh dan tidak berharga dalam hidup, termasuk norma dan sikap yang tercermin dalam cara berpikir dan pola perilaku masyarakat, tertanam kuat, meresap, dan berakar dalam jiwa masyarakatnya sehingga sulit diganti dan/atau diubah dalam waktu yang singkat. Hal inilah yang turut mendasari kajian ini. Pemahaman tersebut dapat diamati melalui unsur bahasa yang disebut ungkapanungkapan tradisional masyarakat Sumbawa di Pulau Lombok yang berbentuk peribahasa (ama samawa).

Masalah yang dibahas dalam kajian ini adalah (1) bagaimanakah wujud ungkapan tradisional, ama samawa, yang ada dalam masyarakat
Sumbawa di Pulau Lombok? dan (2) bagaimanakah orientasi nilai budaya yang terdapat pada ungkapan tradisional, ama samawa, pada masyarakat Sumbawa di Pulau Lombok?

Kajian ini bertujuan untuk menampilkan wujud dan nilai budaya yang terdapat pada ungkapan tradisional, ama samawa, pada masyarakat Sumbawa di Pulau Lombok, yang masuk dalam kategori nilai baik, nilai buruk, nilai netral, dan merujuk pada nilai budaya yang akan dipedomani atau tidak dalam kehidupan masyarakatnya sehari-hari.

Malinowski (Hymes dalam Masinambow) ${ }^{1}$ mengemukakan bahwa melalui etnolinguistik kita dapat menelusuri bagaimanakah bentukbentuk linguistik dipengaruhi oleh aspek budaya, sosial, mental, dan psikologis; apakah hakikat sebenarnya dari bentuk dan makna, serta bagaimanakah hubungan keduanya. Sehubungan dengan adanya konsep tersebut, tulisan ini akan mengkaji pertalian antara bahasa (kosakata) dan nilai budaya masyarakat Sumbawa melalui ungkapan tradisional (ama samawa) dan mengungkapkan nilai budaya yang terkandung di dalamnya. Hal ini dilakukan untuk memberikan asumsi dasar (pemahaman) tentang wujud dari nilai-nilai budaya secara universal, yang pada akhirnya dapat memberikan informasi mengenai nilainilai budaya apa saja yang ada dalam masyarakat Sumbawa dilihat dari 
bentuk-bentuk ama samawa secara kolektif.

Koentjaraningrat ${ }^{2}$ mengemukakan bahwa nilai budaya merupakan konsepsi yang hidup dalam alam pikiran warga masyarakat mengenai hal-hal yang dianggap paling bernilai sehingga biasanya berfungsi sebagai pedoman hidup. Menurut kerangka Kluchohn, dalam Koentjaraningrat ${ }^{3}$ terdapat lima masalah pokok dalam kehidupan manusia, yaitu (1) hakikat hidup manusia; (2) hakikat dari karya manusia; (3) hakikat dan kedudukan manusia dalam ruang dan waktu; (4) hakikat hubungan manusia dengan alam; dan (5) hakikat hubungan manusia dengan manusia lainnya.

Nilai-nilai budaya dalam kajian ini dipahami sebagai hasil aktivitas manusia yang digambarkan melalui ungkapan-ungkapan tradisional, ama samawa, yang menjadi prinsip pedoman bertingkah laku dalam melaksanakan kegiatan yang berhubungan dengan orientasi nilai budaya. Hal ini sekaligus akan dilihat apakah bentuk bahasa ama samawa itu masih dipertahankan seutuhnya dalam bahasa Sumbawa atau malah telah terkontaminasi di tengah kontak bahasa yang dialami di wilayah penutur bahasa pribumi (Sasak) yang dominan.

Ama samawa dalam kajian ini disepadankan dengan peribahasa dalam bahasa Indonesia. Dalam Kamus Besar Bahasa Indonesia, peribahasa didefinisikan sebagai kalimat yang tetap susunannya, biasanya mengiaskan maksud tertentu (dalam peribahasa termasuk juga bidal, ungkapan, perumpamaan). Selain itu, peribahasa juga didefinisikan sebagai ungkapan atau kalimat ringkas padat, berisi perbandingan, perumpamaan, nasihat, prinsip hidup atau aturan tingkah laku. Dananjaya $^{4}$ memasukkan peribahasa (disebut juga dengan ungkapan tradisional) sebagai salah satu contoh folklor lisan Indonesia.

Ama Samawa adalah ungkapan tradisional etnis Sumbawa yang berisi norma, nilai, nasihat, perbandingan, perumpamaan, pedoman, larangan, prinsip hidup atau aturan tingkah laku. Ama Samawa ini selalu menjadi pedoman setiap warganya karena bermanfaat positif dalam menentukan sikap hidup etnis Sumbawa. Ama Samawa banyak digunakan dalam kehidupan keseharian orang pada masa dulu dan diturunkan dari generasi ke generasi karena dianggap sebagai jalan yang paling mudah bagi mereka untuk memberi nasihat, teguran atau sindiran. Demikian sebaliknya, isinya mudah ditangkap oleh pihak yang dinasehati. Bila dicermati, isi dan jiwa yang terkandung dalam ama samawa, berasal dari sejarah, sosial, dan makna kehidupan mereka pada masa itu.

Pengumpulan data dilakukan dengan menggunakan metode observasi dan wawancara. Metode observasi digunakan untuk mendapatkan data bahasa dan unsur kebudayaan masyarakatnya lainnya. Sementara wawancara relatif tertutup 
dilakukan untuk mendapatkan topiktopik khusus atau umum mengenai ungkapan tradisional dan budayanya. Wawancara terbuka dilakukan untuk memberikan kebebasan kepada informan dan mendorongnya untuk berbicara secara luas dan mendalam tentang hal-hal yang diinginkan (Sutopo) $^{5}$.

Informan adalah etnis Sumbawa asli yang tinggal di Pulau Lombok. Pemilihan informan tersebut, sesuai dengan syarat yang telah ditetapkan sebelumnya, yaitu (i) masyarakat Sumbawa asli yang tinggal di Pulau Lombok yang sehat jasmani dan rohani, (ii) mengetahui bahasanya secara mantap dalam pengertian bahwa mereka menguasai bahasanya yang lengkap, (iii) mengetahui latar belakang budayanya, dan (iv) mempunyai cukup waktu dalam memberikan keterangan sesuai dengan apa yang diinginkan.

Metode analisis yang digunakan adalah kualitatif dengan tahapan analisis sebagai berikut: (1) terjemahan harfiah dan bebas; (2) analisis klasifikasi-klasifikasi atau kategorikategori; (3) analisis bentuk-bentuk kebahasaan; (4) analisis konteks budaya (sesuai dengan faktor yang diteliti); dan (5) penafsiran yang kemudian penyimpulan makna ama Samawa yang menyangkut nilai-nilai budaya.
2. Pengidentifikasian Wujud Data Ama Samawa

\subsection{Ama Samawa di Desa Rempung}

Bentuk Ama Samawa yang ada di Desa Rempung sudah mendapatkan pengaruh dari etnis pribumi (Sasak). Hal ini terlihat pada beberapa kosakata yang sebagian berasal dari kosakata etnis Sasak, yakni /ndek/ 'tidak' /berumbuk tarok/ 'menambah (dan) menaruh' /betedeng lekok/ 'ditutupi sirih' /raos/ 'omongan' dan /lelah/ 'lelah' seperti terlihat pada data (3), (4), (12), (14) dan (15) berikut.

(3) lamin ndek to be ilur ndek to $($ ndek $=$ Sasak)

'kalo tidak kita beri ludah tidak dikerjakan'

'kalo tidak diberi perintah, tidak dikerjakan'

'apabila tidak diminta berbuat sesuatu, dia tidak akan melakukannya'

(4) ayam mate berumbuk tarok 'ayam mati menambah menaruh (meletakan)'

'ayam mati (berusaha bangun/menambah kekuatan diri' 'orang yang sudah kalah, menambah kekalahannya lagi'

(12) betedeng lekok seselat 'ditutupi jurang/tanah yang berlubang selembar daun sirih' 'ditutupi (menyembunyikan sesuatu yang besar) tanah yang berlubang dengan selembar daun sirih' 
'bersembunyi pada tempat yang mudah terlihat'

(14) len lelah, len mau upah (lelah = Sasak; upah = Sasak)

'lain lelah, lain mau upah'

'lain berlelah-lelah, lain yang menerima'

'lain orang yang bekerja, lain yang menikmati hasilnya'

(15) ndek bau tu intik raos (ndek = Sasak)

'tidak ada bisa PFK : pegang kata-kata/omongan'

'tidak bisa dipegang katakatanya'

'kata-katanya tidak dapat dipercaya'

Peristiwa kontak antarbudaya yang terjadi adalah peristiwa akulturasi. Peristiwa atau proses akulturasi ini merupakan peristiwa bertemunya dua kebudayaan yang berbeda. Unsur-unsur budaya yang berbeda itu saling bersentuhan dan saling meminjam, tetapi ciri khas masing-masing budaya yang berbeda tidak hilang dan tetap dipertahankan keberadaannya.

Berdasarkan informasi yang diperoleh dari informan, kedatangan etnis Sumbawa Taliwang ke Rempung dimulai pada tahun 1700-an. Pada saat itu Lombok berada di bawah kekuasaan Anak Agung Bali, dengan pusat pemerintahannya di Kota Cakranegara (Mataram). Pada awalnya orang-orang yang menetap di Rempung ini bermukim di Dusun Pringgasari (sekarang menjadi Pringgasela) dan mereka berjumlah sekitar tujuh belas orang.

Ketika terjadi penyerangan oleh orang Bali ke Pringgasela, orang-orang Sumbawa yang tinggal di Rempung ini terdesak ke wilayah Pancor. Akhirnya, mereka meminta bantuan Belanda untuk merebut kembali Pringgasela, dan berhasil. Setelah Pringgasela berhasil direbut, mereka kembali ke Pringgasela. Atas inisiatif sendiri, orang-orang Sumbawa yang tinggal di Pringgasela ini kemudian meninggalkan pemukimannya dan pindah (ke Rempung) untuk membuka lahan garapan perladangan disebuah kawasan hutan yang bernama 'Gawah Rempung Kesambik'. Nama Rempung diambil dari nama pohon besar dan kebanyakan tumbuh di sekitar itu, yaitu rempung kesambik 'rumpun kesambik', yang dalam bahasa Sumbawanya disebut 'purang kesamik'. Pohon kesambik merupakan sejenis pohon yang agak rindang, dan mempunyai buah. Kata Rempung berarti rumpun, selanjutnya diambil sebagai nama pemukiman mereka.

Di samping itu, orang-orang Sumbawa memilih daerah tersebut sebagai pemukimannya yang baru karena di wilayah tersebut ditemukan tete tenaq 'jalan titian'. Tete tenaq ini adalah jalan yang melintasi pemukiman mereka, yang menghubungkan dengan pemukiman-pemukiman lain di wilayah itu (Mahsun) ${ }^{6}$.

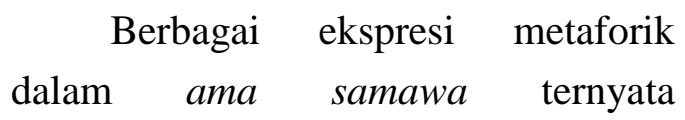


memanfaatkan unit-unit kebudayaan dan pengalaman hidup masyarakat penuturnya, yang terkait dengan ranah tumbuhan, kehewanan, dan kemiripan sifat.

Wujud ama samawa yang menggunakan bentuk dan sifat tumbuhan sebanyak satu data, yaitu:

(12) betedeng lekok seselat 'ditutupi jurang/tanah yang berlubang selembar daun sirih' 'ditutupi (menyembunyikan sesuatu yang besar) tanah yang berlubang dengan selembar daun sirih'

'bersembunyi pada tempat yang mudah terlihat';

Wujud ama samawa yang menggunakan bentuk dan sifat hewansebanyak delapan data, yaitu:

(1) reskibukalnosi etlinggagak 'reski kekelawar tidak diambil oleh burung gagak'

'reski kekelawar tidak diambil oleh burung gagak'

'Setiap orang memiliki rezeki masing-masing',

(2) ajarbote ntekkayu

'mengajar monyet PFK: panjat kayu'

'mengajari monyet memanjat kayu'

'mengajari orang yang sudah mahir',

(4) ayam mate berumbuk tarok

'ayam mati menambah menaruh (meletakan)'

'ayam mati (berusaha bangun/menambah kekuatan diri' 'orang yang sudah kalah, menambah kekalahannya lagi',

(5) bau balangke pontet 'ada belalang di api membara' 'ada belalang di api membara' 'tidak mempunyai simpanan',

(6) yambotebau baling 'ibarat monyet ada belalang' 'ibarat monyet menangkap belalang'

'seseorang yang ingin mendapatkan semua yang diinginkannya, tetapi akhirnya tidak memperoleh apa-apa',

(8) jaran kakan book

'kuda makan bawaan sendiri'

'kuda memakan bawaan sendiri' 'orang yang makan pemberiannya sendiri'

(9) kakan salo bukal 'makan sisa kekelawar' 'makan sisa kekelawar' 'memakan makanan sisa orang lain', dan

(13) alis-alistaijaran

'halus-halus kotoran kuda'

'halus (bersih) berisi kotoran kuda'

'di luar bagus, di dalam jelek';

Wujud ama samawa yang menggunakan bentuk dan kemiripan sifat sebanyak enam data, yaitu:

(3) lamin ndek to be ilur ndek to $($ ndek $=$ Sasak)

'kalo tidak kita beri ludah tidak dikerjakan'

'kalo tidak diberi perintah, tidak dikerjakan' 
'Apabila tidak diminta berbuat sesuatu, dia tidak akan melakukannya'

(7) barari lantar tiang langke 'berusahatanpaperhitungan' 'berusaha tanpa perhitungan' 'berusaha tanpa perhitungan'

(10) tampal pemongkah belaq 'menampal/menambal panik pecah'

'menambal panci yang sudah pecah'

'memakan makanan sisa orang lain', dan

(11) loge dilodaki

'ada keringat ada daki/kotoran tubuh'

'Kalau mengeluarkan keringat, pasti mengeluarkan kotoran'

'Ada usaha, ada hasil'.

Penamaan ama samawa yang menggunakan bentuk dan sifat, tumbuhan, hewan, dan kemiripan sifat tersebut mencerminkan perilaku, sudut pandang dan keyakinan yang dianut penuturnya. Selain itu, bentuk-bentuk yang digunakan juga selalu mengacu pada objek, peristiwa, dan segala sesuatu yang bersifat simbolik dan metaforik. Bentuk dan makna yang dimiliki oleh suatu budaya masyarakat akan membentuk suatu worldview, sebagai suatu cara pandang suatu masyarakat tutur dan sistem kepercayaan yang terbentuk merupakan akibat pengaruh nilai budaya yang dimiliki. Dengan demikian dapat dikatakan bahwa bahasa mencerminkan nilai budaya sebagai identitas suatu masyarakat tutur.

Nilai budaya suatu masyarakat tutur dikemas sedemikian rupa dan menghasilkan varian-varian yang mencerminkan kedinamisan dalam kehidupan bermasyarakat dan menunjukkan cara pandangnya terhadap realita dunia. Sifat tumbuhan, hewan, dan kemiripan sifat, yang terdapat pada data di atas merupakan proses pembelajaran masyarakat Sumbawa yang berlangsung secara terus menerus dan diturunkan dari generasi ke generasi sebagai alat pendidikan.

Cara pandang anggota kelompok masyarakat Sumbawa akan selalu tercermin pada sikap, kepercayaan, dan nilai-nilai. Namun, dewasa ini mulai terjadi pendangkalan nilai moral yang disertai krisis jati diri dan kepribadian. Krisis ini dikhawatirkan dapat mengancam integrasi persatuan bangsa dan kokohnya ketahanan budaya lokal dan nasional. Krisis ini telah menyadarkan segenap komponen masyarakat akan pentingnya ketahanan budaya dalam kehidupan masyarakat. Keinginan bersatu harus dikembangkan dengan dilandasi oleh pertimbangan untuk mewujudkan ketentraman, kesejahteraan, dan harapan hidup yang sesuai dengan nilai budaya untuk mewujudkan keharmonisan dalam masyarakat. Perilaku budaya, seperti kehalusan budi dalam pergaulan dan rasa keadilan serta keseimbangan antara hak dan kewajiban merupakan 
hakikat nilai-nilai penting yang harus ada dalam interaksi manusia. Aturan mengenai hubungan yang harmonis antarmanusia itu sudah terkristal dalam ama samawa. Hal ini berarti bahwa unsur bahasa dalam bentuk ama samawa berfungsi sebagai penyampai nilai budaya

\subsection{Ama Samawa di Dusun Kuang} Berora

Kuang Berora merupakan salah satu dusun di Desa Sakra, Kecamatan Sakra, Kabupaten Lombok Timur. Letak Dusun Kuang Berora sangat strategis dari segi keamanan. Meskipun dusun ini termasuk wilayah Desa Sakra, penduduknya terpusat pada satu tempat, yang dipisahkan oleh batasbatas yang tegas berupa areal persawahan dan perbukitan. Lokasi dusun ini membuat wilayah ini relatif aman karena hanya memiliki satu pintu masuk yang menghubungkannya dengan wilayah-wilayah sekitarnya, yaitu jalan yang menghubungkannya dengan pusat desa dan kecamatan.

Secara geografis, masyarakat di Dusun Kuang Berora ini termasuk masyarakat plural, yang hidup berdampingan dengan beberapa etnis, yakni etnis Sumbawa, Jawa, dan etnis Sasak sebagai etnis pribumi. Sebagian besar masyarakat di Dusun Kuang Berora ini adalah etnis pendatang dari Pulau Sumbawa dan merupakan salah satu penutur bahasa Sumbawa Dialek Jereweh di Lombok. Akan tetapi, jarak komunitas Kuang Berora dengan masyarakat Sasak yang ada di sekitarnya cukup jauh, sehingga bentuk-bentuk kerja sama antaretnis yang melibatkan mereka relatif kecil.

Penduduk Dusun Kuang Berora sebagian besar bermatapencaharian sebagai tukang kayu untuk bangunan rumah. Selain itu, mata pencaharian mereka adalah sebagai petani, pedagang, dan buruh. Peluang interaksi dengan etnis Sasak sekitarnya dimungkinkan terjadi berkaitan dengan adanya satu jalan yang menghubungkan Kuang Berora dengan pusat desa dan kecamatan, serta berkaitan dengan mata pencaharian masyarakat Kuang Berora, baik sebagai tukang kayu, pedagang, maupun buruh, dalam upaya menawarkan jasa atau barang, sehingga menuntut mereka untuk bersikap dinamis.

Ama samawa yang ada di Dusun Kuang Berora masih tetap mempertahankan bentuk dan makna yang terkandung di dalamnya.

Wujud ekspresi metaforik dalam ama samawa yang menggunakan bentuk dan sifat tumbuhan sebanyak satu data berikut.

(16) orasairolapoto

'menggeret bambu dari
ujungnya'
'menggeret bambu dari
ujungnya'
'mengajak bekerja orang yang
sangat malas';

Wujud ekspresi metaforik dalam ama samawa yang menggunakan bentuk 
dan sifat hewan sebanyak lima data, yaitu:

(18) ketuma dalam kerik

'kutu dalam sarung'

'kutu di dalam sarung'

'musuh dalam selimut',

(20) marabodok sumekkuku

'seperti kucing PFK:

sembunyikan kuku'

'seperti kucing menyembunyikan

kuku'

'seperti kucing menyembunyikan

kukunya, padahal dia mempunyai

kemampuan'

(21) kausipat mara temuan geti

'kau sifat seperti tawon'

'sifatnya seperti tawon'

'orang yang tidak bisa diganggu

dan cepat marah'

(22) etesipat ayam ngaram

'PFK: ambil sifat ayam

mengeram'

'mengambil sifat ayam

mengeram'

'orang yang tidak bisa diganggu

dan cepat marah', dan

(24) yammayungtarigawe

'seperti menjangan PFK: tunggu pekerjaan'

'seperti rusa menunggu

pekerjaan'

'seperti orang yang tidak ada pekerjaan; sukanya bermalas-

malasan';

Wujud ekspresi metaforik dalam ama samawa yang menggunakan bentuk dan kemiripan sifat sebanyak empat data, yaitu:
(17) yam api oram

'ibarat api sapu'

'ibarat api (yang menyala) (lalu tiba-tiba) dibersihkan(sapu)'

'orang yang memiliki hasrat dan keinginan tinggi, tetapi sifatnya sementara',

(19) bakarante no gita bungkak angkang

'berbicara tidak melihat belakang depan'

'berbicara tidak mau melihat belakang depan'

'berbicara tanpa memikirkan

perasaan orang lain',

(25) notubeangilur, nobatisu

'tidak kita beri ludah, tidak meludah'

'tidak kita beri ludah, dia tidak akan meludah'

'apabila tidak diminta berbuat

sesuatu, dia tidak akan

melakukannya', dan

(27) ngaluguguntirbalit

'berkecamuk petir kemarau'

'banyak petir dimusim kemarau'

'orang yang banyak bicara, tetapi miskin ilmu';

Wujud ekspresi metaforik dalam ama samawa yang menggunakan bentuk dan sifat angota badan sebanyak dua data, yaitu:

(23) ingotusatowemata

'melihat kita sebelah mata'

'melihat dengan sebelah mata'

'orang yang kurang memedulikan orang lain'dan 
(26) telaspangbaootakdengan

'hidup diatas kepala teman'

'hidup diatas kepala teman'

'orang yang hidup di atas

penderitaan orang lain'

Metafora adalah salah satu artefak budaya yang mengandung nilainilai dan melibatkan konseptualisasi dari suatu wilayah untuk merepresentasikan sesuatu yang lain. Proses ini diberi istilah mapping. Oleh karena itu, metafora merupakan penerapan dari sebuah satuan konseptual ke satuan konseptual yang lainnya. Dalam hal ini, penutur masyarakat Sumbawa Kuang Berora memilih sendiri cara pandangnya terhadap nilai budaya lokal untuk dijadikan perisai, penangkis, dan penyaring budaya global demi tercapainya keserasian hidup. Penggalian tentang nilai-nilai budaya yang terdapat dalam ungkapan metafora tersebut dapat dijadikan dasar dalam menggalang rasa kesetiakawanan, semangat bekerjasama, dan pengembangan sumber daya manusia.

Penggunaan bentuk-bentuk metafora pada data di atas merupakan pemahaman dari pengalaman (budaya) masyarakat Sumbawa terhadap suatu hal yang dimaksudkan untuk perihal yang lain. Di samping itu, bahasa mengategorikan realitas budayabahasa menampilkan sistem klasifikasi yang dapat digunakan untuk menelusuri praktik-praktik budaya dalam suatu masyarakat.
Model-model budaya dapat dimunculkan secara eksplisit melalui wujud ama samawa. Model-model budaya (dalam metafora) yang dimaksudkan di sini antara lain mencakup mentalitas kerja, persepsi rasa solidaritas, sikap, perilaku, etika, dan moral.

\section{Nilai Budaya Etnis Samawa yang Tercermin dalam Ama} Samawa

Nilai budaya yang terkandung dalam ama samawa ini dikelompokkan berdasarkan makna atau informasinya. Artinya, hakikat hubungan manusia dengan hidup dapat ditelusuri pada korpus kajian ini.

Hakikat hubungan manusia dengan hidup tercermin dalam enam data ama samawa ini memuat tentang nilai yang mengacu pada kebijaksanaan, hasrat, dan perasaan.

Kebijaksanaan. Nilai yang mengacu pada kebijaksanaan manusia itu terdapat satu data ama samawa, yaitu seperti pada (1) berikut.

(1) reskibukanosi etelinggagak

'reski kekelawar tidak diambil oleh burung gagak'

'reski kekelawar tidak diambil oleh burung gagak'

'Setiap orang memiliki rezeki masing-masing'

Berdasarkan data (1), masyarakat Sumbawa memandang rezeki itu berasal dari Allah dan setiap manusia memiliki rezeki masing-masing. Penggunaan bentuk 'bukal' yang 
berarti 'kekelawar' dan 'gagak' yang berarti 'burung gagak' secara bersamaan menunjukkan bahwa meskipun berangkat dari asumsi, kedua binatang tersebut mempunyai kesamaan jenis, binatang malam, mereka masih bisa eksis, melanjutkan kehidupannya, sendiri-sendiri. Realitas kehidupan yang berakar pada kebenaran hakiki (percaya akan Tuhan) menjadi konsep yang sangat diyakini dan diwujudkan dalam sikap dan tindakan mereka. Hal ini tidaklah mengherankan karena mayoritas masyarakat Samawa saat ini memeluk agama Islam dan konsep kehidupan, baik pendidikan, etika pergaulan hidup, perkawinan, maupun segala bentuk tradisi dan adat istiadat disesuaikan dengan ajaran Islam.

Mereka tidak takut untuk menjalani berbagai corak kehidupan di dunia ini di mana pun keberadaannya. Mereka meyakini bahwa Tuhan-lah atau Allah SWT menjadi tempat mereka bergantung dan meminta. Mereka memandang hidup adalah tantangan yang harus diatasi dengan kerja keras dan berdoa.

Hasrat. Nilai yang mengacu pada hasrat manusia itu terdapat dua data, yaitu seperti pada (6) dan (17) berikut.

(6) yambotebau balang

'ibarat monyet ada belalang'

'ibarat monyet menangkap belalang' 'seseorang yang ingin

mendapatkan semua yang diinginkannya, tetapi akhirnya tidak memperoleh apa-apa'

(17) yamapi oram

'ibarat api sapu'

'ibarat api (yang menyala) (lalu tiba-tiba) dibersihkan(sapu)'

'orang yang memiliki hasrat dan keinginan tinggi, tetapi sifatnya sementara'

Ama Samawa yang terdapat pada (6) dan (17) merupakan pedoman masyarakat Sumbawa dalam memandang etika kehidupan, bahwa orang harus memiliki hasrat/keinginan yang tinggi dalam mewujudkan citacita atau impian. Hasrat atau keinginan tersebut juga harus diimbangi dengan usaha dan doa, kesabaran dan keuletan, dan tidak tergesa-gesa.

Ama Samawa yang terdapat pada (17) 'yam api oram' merupakan bentuk sindiran terhadap seseorang yang memiliki cita-cita dan semangat yang tinggi, tetapi cita-cita dan semangat tinggi tersebut hanya bersifat sementara, sehingga gagal untuk mewujudkan impian. Selain digunakan untuk menyatakan sindiran, ama samawa (17) tersebut mengandung nasehat, bahwa untuk dapat mewujudkan cita-cita atau impian harus bekerja keras, tanpa patah semangat, sabar, dan tawakal.

Perasaan. Nilai yang mengacu pada perasaan manusia itu terdapat tiga data ama samawa, yaitu seperti pada (8), (9), dan (10) berikut. 
(8) jaran kakan boko

'kuda makan bawaan sendiri'

'kuda memakan bawaan sendiri'

'orang yang makan

pemberiannya sendiri'

Berdasarkan data (8), masyarakat Sumbawa memiliki konsep bahwa jika memberi sesuatu (hadiah) kepada orang lain, pantang ikut menikmati. Jika hal tersebut dilanggar, akan menerima malu, baik itu secara individu atau pun keluarga. Akan tetapi, nilai budaya yang sangat kental dengan pesan moral tersebut mulai pudar. Hal ini disebabkan situasi budaya modern. Dengan asas kebersamaan dan kekeluargaan, hadiah tersebut dapat dinikmati bersama-sama, baik itu oleh pemberi maupun penerima.

(9) kakan salo bukal

'makan sisa kekelawar'

'makan sisa kekelawar'

'memakan makanan sisa orang lain'

(10) tampal pemongkah belaq

'menampal/menambal panik pecah'

'menambal panci yang sudah pecah'

'memakanmakanan sisa orang lain'

Berdasarkandata (9) dan (10), masyarakat Sumbawa memiliki konsep bahwa hidup itu bertujuan untuk menjadi seseorang yang baik dan benar (bahkan sempurna) untuk diri sendiri, keluarga, sanak saudara, dan Tuhan. Konsep untuk menjadi baikdan benar merupakan motivasi bagi masyarakat
Sumbawa dalam segala tindakan untuk mewujudkan setiap impiannya (menjaga segala tindakan). Setiap segi kehidupan harus mampu memberikan dan mewujudkan sesuatu yang terbaik untuk diri, keluarga, dan sanak saudara. Untuk menjadi baik dan benar itu merupakan sesuatu amanah yang tidak boleh dilanggar. Jika hal tersebut dilanggar, akan menerima malu, baik itu secara individu atau pun keluarga.

Ama Samawa yang terdapat pada (9) 'kakan salo bukal' merupakan bentuk sindiran terhadap seseorang yang (dianggap oleh masyarakat) kurang tepat dalam bersikap. Misal, penggunaan 'kakan salo bukal' ini merupakan bentuk sindiran. Dalam hal ini, misalnya, seorang perempuan berpacaran dengan si A. Akan tetapi, di tengah perjalanan cintanya, perempuan ini putus dan tidak jadi menikah dengan A. Lalu, perempuan ini berpacaran dengan si $\mathrm{B}$, dan pada akhirnya perempuan ini menikah dengan B. Penggunaan 'kakan salo bukal' ini untuk menyindir keberadaan atau kondisi si B karena B telah bersikap (mengambil keputusan) untuk memperistri perempuan tersebut. Masyarakat beranggapan bahwa B telah memperistri bekas pacar A. Meskipun perempuan ini masih menjaga kesuciannya, baik si perempuan maupun si B tetap dilihat sisi negatifnya karena perempuan tersebut pernah berpacaran dengan si A (dalam hal ini $\mathrm{B}$ hanya mendapatkan sisa dari A). 
Data (10) 'tampal pemongkah belaq' merupakan bentuk sindiran terhadap seseorang yang (dianggap oleh masyarakat) kurang tepat dalam bersikap. Dalam hal ini, misalnya, seorang perempuan berpacaran dengan si A. Pada saat berpacaran dengan si A, perempuan ini hamil (memiliki anak), tetapi belum diikat tali perkawinan, dan perempuan ini tidak jadi menikah dengan si A. Lalu, perempuan ini berpacaran dengan si $\mathrm{B}$, dan pada akhirnya perempuan ini menikah dengan B. Penggunaan 'tampal pemongkah belaq' ini untuk menyindir keberadaan atau kondisi si B karena B telah bersikap (mengambil keputusan) untuk memperistri perempuan tersebut. Masyarakat beranggapan bahwa $\mathrm{B}$ telah memperistri bekas pacar A.

Jika seandainya si perempuan pernah menikah dengan si A dan mempunyai anak, lalu bercerai hidup/mati, dan di kemudian hari si perempuan ini menikah dengan si $\mathrm{B}$, masyararakat tetap beranggapan bahwa si B telah memperistri bekas istri orang. Sampai kapan pun, si B tetap akan mendapatkan sindiran 'tampal pemongkah belaq' dan masyarakat kurang dapat memaafkan atau menerima kondisi si B.

Berdasarkan ilustasi di atas, satu hal menarik dalam sistem perkawinan masyarakat Samawa, yang dianggap ideal adalah perkawinan antarsaudara sepupu. Hal ini mengindikasikan bahwa adat-istiadat perkawinan dalam masyarakat Samawa adalah mengutamakan mencari pasangan dari kerabat sendiri yang sering pula dirumuskan dalam ungkapan 'pekopeko kebo dita' atau 'biar bengkok, tapi kerbau sendiri', yang bermakna bangga terhadap kediriannya dan lebih mengutamakan milik sendiri.

Dalam perkawinan adat Samawa juga terdapat pantangan yang dinamakan kawin sala basa atau perkawinan yang naif dilakukan karena dianggap tidak sejajar dalam garis silsilah sehingga dianggap kurang santun dalam pandangan adat, seperti seorang paman mengawini anak saudara sepupunya, walaupun dalam syariat Islam diperbolehkan.

\section{Simpulan dan Saran}

\subsection{Simpulan}

Bentuk ama samawa yang berhasil diinventariskan penulis, baik di Desa Rempung maupun Dusun Kuang Berora, memanfaatkan unit-unit kebudayaan dan pengalaman hidup masyarakat penuturnya, yang terkait dengan ranah tumbuhan, kehewanan, dan kemiripan sifat. Penamaan ama samawa yang menggunakan bentuk dan sifat, tumbuhan, hewan, dan kemiripan sifat tersebut mencerminkan perilaku, sudut pandang dan keyakinan yang dianut penuturnya.Selain itu, bentuk-bentuk yang digunakan juga selalu mengacu pada objek, peristiwa, dan segala sesuatu yang bersifat simbolik dan metaforik.

Ama samawa yang ada di Desa Rempung bentuknya sudah 
mendapatkan pengaruh dari etnis pribumi (Sasak). Hal ini terlihat pada beberapa kosakata-kosakatanya yang sebagian berasal dari kosakata etnis Sasak, yakni 'ndek' berati 'tidak'; 'berumbuk tarok' berarti 'menambah (dan) menaruh'; 'betedeng lekok' berarti 'ditutupi sirih'; 'raos' berarti 'omongan' dan 'lelah' berarti 'lelah'. Peristiwa kontak antarbudaya yang terjadi adalah peristiwa akulturasi. Lain halnya, ungkapan-ungkapan tradisional yang ada di Dusun Kuang Berora, khususnya ama (peribahasa) samawa, masih tetap mempertahankan bentuk dan makna yang terkandung di dalamnya.

Nilai budaya yang terkandung dalam ama samawa ini dikelompokkan berdasarkan makna atau informasinya. Hakikat hubungan manusia dengan hidup tercermin dalam enam data ama samawa ini memuat tentang nilai yang mengacu pada kebijaksanaan, hasrat, dan perasaan.

Kemunculan secara kolektivitas nilai budaya pada masyarakat Sumbawa itu didasarkan pada pentingnya hidup manusia dan hubungan dengan sesama. Pentingnya hidup ini merupakan sesuatu yang mendasar dan harus dipenuhi oleh masyarakat Sumbawa, sebagai etnis pendatang di Pulau Lombok, mengingat keberadaan dan eksistensi dirinya harus bertahan hidup di wilayah dan hegemoni hidup masyarakat Sasak. Apabila hal ini tidak dijalankan, akan terjadi pergeseran makna kebersamaan dan dapat menjadi konflik di antara mereka, terutama antara etnis pendatang dengan etnis pribumi.

\subsection{Saran}

Kajian ini dapat menjadi masukan yang sangat berarti bagi pemerintah agar dalam pengembangan, pemberdayaan, dan peningkatan taraf kesejahteraan sesuai dengan karakteristik sistem pengetahuan dan nilai budaya masyarakatnya sehingga pelaksanaan program pemerintah itu dapat diterima oleh masyarakatnya di mana pun mereka berada. 


\section{DAFTAR PUSTAKA}

${ }^{1}$ Masinambow. 1998. "Hubungan Timbal Balik antara Bahasa dan Kebudayaan”. Makalah pada Pertemuan Pra-kuliah Program Studi Masalah Linguistik dan Kajian Budaya Universitas Udayana Denpasar". Tahun Akademik 1998/1999, 20—24 Juli.

${ }^{2}$ Koentjaraningrat. 2009. Pengantar Ilmu Antropologi. Jakarta: Rineka Cipta.

${ }^{3}$ Koentjaraningrat. 2009. Pengantar Ilmu Antropologi. Jakarta: Rineka Cipta.

${ }^{4}$ Danandjaya, James. 1984. Foklor Indonesia Ilmu Gosip, Dongeng, dan lain-lain. Jakarta: Rineka Cipta.

${ }^{5}$ Sutopo, H.B. 1996. Metode Penelitian Sosial. Surakarta: Sebelas Maret University Press.

${ }^{6}$ Mahsun. 2006. Bahasa dan Relasi Sosial. Yogyakarta: Gama Media. 